\title{
Blood-brain barrier transport of amyloid beta peptides in efflux pump knock-out animals evaluated by in vivo optical imaging
}

Wandong Zhang ${ }^{1,2^{*}}$, Huaqi Xiong ${ }^{1,2,3}$, Debbie Callaghan ${ }^{1}$, Hong Liu' ${ }^{1}$, Aimee Jones ${ }^{1}$, Ke Pei ${ }^{1,4}$, Dorothy Fatehi ${ }^{1}$, Eric Brunette ${ }^{1}$ and Danica Stanimirovic ${ }^{1,2}$

\begin{abstract}
Background: $A \beta$ transport (flux) across the blood-brain barrier (BBB) is thought to contribute to the pathogenesis of Alzheimer's disease as well as to elimination of toxic amyloid from the brain by immunotherapy. Several BBB transporters have been implicated in $A \beta$ exchange between brain parenchyma and the circulation, including efflux transporters P-glycoprotein/ABCB1 and BCRP/ABCG2. Here we describe an application of in vivo optical imaging methods to study $A \beta$ transport across the $B B B$ in wild-type or animals deficient in specific efflux transporters.

Methods/Design: Synthetic human $A \beta_{1-40}$ or scrambled $A \beta_{40-1}$ peptides were labeled with the near-infrared fluorescent tracer, Cy5.5. The free tracer or Cy5.5-labeled peptides were injected intravenously into Abcb1-KO or $\mathrm{Abcg} 2^{-\mathrm{KO}}$ mice or their corresponding wild-type controls. The animals were imaged prospectively at different time points over a period of 8 hours using explore Optix small animal imager. At the end of the observation, animals were sacrificed by perfusion, their brains were imaged ex-vivo and sectioned for immunofluorescence analyses.

Discussion: After appropriate circulation time, the fluorescence concentration in the head ROI measured in vivo was close to background values in both wild-type and $\mathrm{Abcb} 1^{-\mathrm{KO}}$ or $\mathrm{Abcg} 2^{-\mathrm{KO}}$ mice injected with either free dye or scrambled $A \beta_{40-1}-C y 5.5$. In animals injected with $A \beta_{1-40}-C y 5.5$, the deficiency in either $A b c b 1$ or $A b c g 2$ resulted in significant increases in fluorescence concentration in the head ROls 2 hours after injection compared to wild-type animals. Fluorescence decay (elimination rate) over 2-8 hours after injection was similar between wild-type $\left(\mathrm{t}_{1 / 2}=1.97 \mathrm{~h}\right)$ and $\mathrm{Abcg}^{-\mathrm{KO}}\left(\mathrm{t}_{1 / 2}=2.34 \mathrm{~h}\right)$ and was slightly faster $\left(\mathrm{t}_{1 / 2}=1.38 \mathrm{~h}\right)$ in $\mathrm{Abcb}^{-\mathrm{KO}}$ mice. In vivo timedomain imaging method allows prospective, dynamic analyses of brain uptake/elimination of fluorescently-labeled compounds, including $A \beta$. Deficiency of either of the two major efflux pumps, Abcb1 and Abcg2, implicated in $A \beta$ trafficking across the $B B B$, resulted in increased accumulation of peripherally-injected $A \beta_{1-40}$ in the brain.
\end{abstract}

Keywords: Alzheimer's disease, A $\beta$ peptides, Blood-brain barrier, Mdr-1a/b P-glycoprotein, Abcb1a/b, Abcg2, Optical imaging

\section{Background}

Alzheimer's disease (AD) is a chronic neurodegenerative disease characterized, among other neuropathological features, by the accumulation, aggregation and deposition of beta-amyloid peptides (A $\beta$ peptides) in the brain $[1,2]$. $A \beta$ peptides form oligomers, aggregates and plaques which are thought to contribute to synaptic dysfunction,

\footnotetext{
* Correspondence: Wandong.Zhang@nrc.ca

'Human Health \& Therapeutics Portfolio, National Research Council of Canada, Ottawa, Canada

${ }^{2}$ Faculty of Medicine, University of Ottawa, Ottawa, Canada

Full list of author information is available at the end of the article
}

neuroinflammation and neurodegenerative pathology in Alzheimer's disease [1-4].

Mechanistic studies have generated a substantial body of evidence that brain accumulation of $A \beta$ peptides is not solely due to their increased production in the brain, but also to reduced brain clearance and/or increased uptake from peripheral circulation [5,6]. Both latter processes are controlled by the polarized blood-brain barrier (BBB) receptors and transporters [7-10]. Blood-borne $A \beta$ is taken up into the brain by the luminally-expressed endothelial receptor for advanced glycation end-products

\section{Ciomed Central}

(c) 2013 Zhang et al.; licensee BioMed Central Ltd. This is an Open Access article distributed under the terms of the Creative Commons Attribution License (http://creativecommons.org/licenses/by/2.0), which permits unrestricted use, distribution, and reproduction in any medium, provided the original work is properly cited. 
(RAGE) [11,12], whereas its brain efflux/clearance is largely mediated by the abluminal low-density lipoprotein receptor-related protein 1 (LRP1) $[5,6,13,14]$. A soluble form of LRP1 (sLRP1) is the major endogenous peripheral $\mathrm{A} \beta$ 'sink' that sequesters some 70 to $90 \%$ of plasma $A \beta$ peptides [5]. Recent evidence also implicated key $A B C$ family $\mathrm{BBB}$ transporters in $\mathrm{A} \beta$ trafficking between brain and circulatory compartments; luminal efflux transporter ABCG2 has been shown to prevent blood-borne $A \beta$ from entry into the brain $[8,15,16]$, whereas BBB P-glycoprotein /ABCB1's role in the brain clearance of $A \beta$ has been demonstrated in both in vitro and transgenic $\mathrm{AD}$ models [16-20]. It is important to note that shuttling of $A \beta$ across the $\mathrm{BBB}$ occurs by receptor/transporter-mediated processes that require the intact tertiary structure of the peptide that interacts with the carrier receptor(s).

$\mathrm{A} \beta$ brain intake and brain clearance have been studied using radioisotope-labeled $A \beta$ peptides injected systemically or stereotactically into the brain, and by monitoring their appearance in various compartments, including cerebral spinal fluid (CSF) [21]. A molecular imaging tracer, $\left[{ }^{11} \mathrm{C}\right]$-Pittsburgh compound $\mathrm{B}$ (PiB), which binds to $\mathrm{A} \beta$ plaques, has been used in smallanimal and human PET (positron-emission tomography) imaging studies to monitor $A \beta$ plaque load and its clearance in response to treatment [22]. The purpose of this study protocol is to demonstrate the utility of a simple and accessible in vivo optical imaging method for studying $\mathrm{A} \beta$ trafficking across the BBB in experimental animals in a dynamic, prospective fashion not achievable with radioactive tracers. Using this method, we demonstrated differences in $\mathrm{A} \beta$ trafficking across the $\mathrm{BBB}$ in animals deficient in two major $\mathrm{ABC}$ efflux pumps, mdr-1 Pglycoprotein/Abcb1 and Abcg2.

\section{Methods and design Materials}

Synthetic human $A \beta_{1-40}$ and scrambled $A \beta_{40-1}$ peptides were purchased from Biopeptides Co., Inc (San Diego, CA, USA). Cy5.5 labeling kits (Cy5.5 ${ }^{\mathrm{TM}}$ Mono NHS ester) and ECL Plus reagent kits were purchased from Amersham Biosciences/GE Healthcares (Buckinghamshire, UK). A mouse monoclonal anti-A $\beta$ antibody $6 \mathrm{E} 10$ was purchased from the Covance Inc (Montreal, QC, Canada), and a goat anti-mouse secondary antibody conjugated with Alexa 568 and a HRP-conjugated donkey anti-mouse IgG antibody were purchased from the Santa Cruz Biotech Inc (Santa Cruz, CA, USA). Fluorescein-labeled lectin, Ulex europeaus agglutinin (UEA-I), was purchased from Vector Laboratories Inc (Burlington, ON, Canada). Fetal bovine serum (FBS) was purchased from Hyclone Inc (Logan, Utah, USA). Dulbecco's phosphate-buffered saline (1X) (PBS) was purchased from GIBCO/Invitrogen (Invitrogen
Inc., Grand Island, NY, USA). Autoradiography films were purchased from Mandel Scientific (Guelph, ON, Canada).

\section{$A \beta$ peptides preparation and labeling}

$\mathrm{A} \beta_{1-40}$ peptide used in this study for optical imaging/ tracking is the most abundant $A \beta$ peptide found in the cerebral vasculature and is more soluble than $A \beta_{1-42}$ peptide. $\mathrm{A} \beta_{1-40}$ peptides (1 $\left.\mathrm{mg} / \mathrm{vial}\right)$ were dissolved in $250 \mu \mathrm{L}$ of $10 \mathrm{mM} \mathrm{NaOH}$, and then $12.5 \mu \mathrm{L}$ of $1 \mathrm{M}$ HEPES [4-(2-hydroxyethyl)-1-piperazineethanesulfonic acid] was added to bring the $\mathrm{pH}$ to 8.0. The peptides were divided into 2 tubes $(0.5 \mathrm{mg} /$ tube $)$ and kept at $-80^{\circ} \mathrm{C}$. Because $A \beta$ peptides are commonly present as beta sheet structure in solution, Western blot analyses of the mixtures were performed, and the majority of the peptides (>95\%) were monomers with a small proportion of dimers (data not shown). $A \beta_{1-40}$ or scrambled $A \beta_{40-1}$ peptides (0.5 mg, molecular weight 4329.86D) were labeled with the nearinfrared fluorescent dye Cy5.5 (molecular weight 1128.42D) using the labeling kit (Cy5.5 ${ }^{\mathrm{TM}}$ Mono NHS ester) as per manufacturer's instructions [8].

Cy5.5 is a monofunctional dye with absorbance at $675 \mathrm{~nm}$, extinction maximum of $250,000 \mathrm{M}^{-1} \mathrm{~cm}^{-1}$, and emission maximum of $694 \mathrm{~nm}$. The functional group commonly used for labelling peptides and proteins is the primary amino group provided by lysine or the $\mathrm{N}$ terminal amino group. The labelling with Cy5.5 NHS ester utilizes acylation reaction at the amino group. The $\mathrm{N}$-terminal amino group and two lysine residues present in both $A \beta_{1-40}$ and scrambled $A \beta_{40-1}$ peptides may be accessible to labelling with Cy5.5 dye. Thus, A $\beta_{1-40}$ peptides can be efficiently labelled with Cy5.5 and then purified free from unincorporated dye for optical imaging. The Cy5.5-labeled peptide can be either injected into the systemic circulation or into the brain to monitor its transport across the BBB.

A $\beta$ peptides $(0.5 \mathrm{mg}$ peptide) were added to $40 \mu \mathrm{L}$ of carbonate buffer ( $\mathrm{pH}$ 9.1) and $20 \mu \mathrm{L}$ of Cy5.5 NHS Ester dye $(200 \mu \mathrm{g}$ in DMSO) and incubated in the dark with rotation at room temperature for at least $2 \mathrm{~h}$. The molecular weight of a labeled $A \beta$ peptide is up to 7715 Dalton. The labeled peptides were purified using a column Microcon Ultracel YM-3 (Regenerated cellulose 3000 MWCO, Millipore Corp., Bedford, MA, USA) to remove unincorporated Cy5.5. The amount of labeled peptides was quantified using a BCA Protein Assay kit (Thermo Scientific, Rockford, IL, USA) following the manufacturer's instructions and the labeling efficiency was determined by the BioTek $\mathrm{FL} \times 800$ microplate reader (673 nm for excitation and $692 \mathrm{~nm}$ for emission). The labeling efficiency/molar ratio was two-three Cy5.5 molecules per $A \beta$ peptide, and was the same for $A \beta_{1-40}$ and the scrambled $A \beta_{40-1}$. The purified $A \beta$ peptides $(100 \mu \mathrm{g}$ in $100 \mu \mathrm{L})$ were diluted with $100 \mu \mathrm{L}$ saline to a 
final volume of $200 \mu \mathrm{L}$ and injected intravenously into mice.

\section{$A \beta-C y 5.5$ conjugate stability in serum}

To evaluate $A \beta-C y 5.5$ conjugate stability in serum, the labeled peptide $(5-\mu \mathrm{L}$ volume containing $\sim 1 \mu \mathrm{g} \mathrm{A} \beta)$ was added to either $35 \mu \mathrm{L}$ of (non-inactivated) FBS or $35 \mu \mathrm{L}$ of $1 \times \mathrm{PBS}$ (1: 8 dilution) and incubated at $37^{\circ} \mathrm{C}$ for 0 , $0.5,1,2,4,6$, and 8 hours, respectively. The peptides $(4 \mu \mathrm{L})$ from each of the above reactions $(40 \mu \mathrm{L} /$ reaction $)$ were added to the loading buffer, boiled for $10 \mathrm{~min}$, and resolved on a 16\% Tricine-SDS-PAGE as described [23]. The tricine-SDS-PAGE gel was scanned in the optical imager; the peptides in the gel were then transferred to a PVDF membrane for immuno-blotting [8]. A mouse monoclonal anti-human $\mathrm{A} \beta$ antibody 6E10 (1:1000 dilution) and the secondary HRP-conjugated donkey antimouse IgG antibody (1:5000 dilution) were used for immunodetection. ECL plus detection reagents were applied to the blots and the blots were exposed to autoradiography films.

\section{Animals}

The experiments with animals have been approved by the Animal Care Committee of the National Research Council of Canada - Ottawa (NRC). Wild-type (wt), mdr1a/b (Abcb1a/b) knockout $\left(\mathrm{Abcb}^{\mathrm{KO}}\right)$, and $\mathrm{Abcg}^{-\mathrm{KO}}$ mice of FVB background were purchased from the Taconic Farms Inc (New York, USA) and maintained in the NRC Animal Facility at Ottawa. Pairs of adult wild-type mice and $\mathrm{Abcb1}^{-\mathrm{KO}}$ and pairs of adult wild-type and $\mathrm{Abcg} 2^{-\mathrm{KO}}$ mice of the same body weight and same sex were matched for injections and imaging experiments. After initial testing of fluorescence signal with various injected doses of Cy5.5-labeld $A \beta$ peptides, the optimal dose selected for the experiments was $100 \mu \mathrm{g}$ of labelled peptide in $200-\mu \mathrm{L}$ volume. The mice were injected via tail vein with free Cy5.5 dye ( 78 $\mu \mathrm{g}$ in $200 \mu \mathrm{L}$ volume) or Cy5.5-labeled $\mathrm{A} \beta_{1-40}(100 \mu \mathrm{g}$ in $200 \mu \mathrm{L}$ volume $)$ or $\mathrm{A} \beta_{40-1}$ peptides (100 $\mu \mathrm{g}$ in $200 \mu \mathrm{L}$ volume) and were imaged in eXplore Optix 670 (GE Healthcare Systems/ART Inc) at different time-points after the injection as described below.

\section{Time-domain in vivo optical imaging}

One week before the experiments, animals were placed in cages with bedding that, if ingested, does not produce in vivo autofluorescence. The animals were anesthetized with inhaled isoflurane ( $4 \%$ for induction and 1.5\% for maintenance) and the fur was shaved from the head and dorsal side of the body. The labeled peptides $(100 \mu \mathrm{g})$ or Cy5.5 free dye $(\sim 78 \mu \mathrm{g})$ were injected intravenously (i.v.) via the tail vein. The animals were imaged at $2,4,6$, and $8 \mathrm{~h}$ post-injection using the time-domain optical imager eXplore Optix 670 (GE Healthcare Systems/ART Inc).
The imaging protocols were described in detail previously [8,24-27].

Briefly, each animal was positioned on a platform (dorsal side facing up) that was then placed on a heated plate $\left(\right.$ at $36^{\circ} \mathrm{C}$ ) in the imaging system. The whole-body scan or selected region of interest (ROI) scan (i.e., head) was performed as described [25,27]. In all imaging experiments, a $670-\mathrm{nm}$ pulsed laser diode with a repetition frequency of $80 \mathrm{MHz}$ and a time resolution of $12 \mathrm{ps}$ was used for excitation. The fluorescence emission at $700 \mathrm{~nm}$ was collected by a highly sensitive photomultiplier tube offset by $3 \mathrm{~mm}$ for diffuse optical topography reconstruction. The optical imager uses a Time-Correlated Single Photon Counting (TCSPC) detection system coupled with a pulsed laser source. Images are built point per point in a raster scan fashion. The combination of a raster-scanning approach with a pulsed laser excitation reduces background and allows for depth probing. A pulsed light source and time-resolved detection allows the system to resolve the nanosecond timescale of fluorescence emission. Each scanned point acquired with the system contains a photon time-of-flight distribution (also called a Temporal Point Spread Function or TPSF). Laser power and counting time per pixel were optimized at $60 \mathrm{~mW}$ and 0.5 seconds, respectively. The values remained constant during the entire experiment. The raster scan interval was $1.5 \mathrm{~mm}$ and was held constant during the acquisition of each frame, and 1,024 points were scanned for each ROI. The data were thus recorded as TPSF and the images were reconstructed as fluorescence concentration maps. Average fluorescence concentration data from ROI placed around the heads were subsequently analyzed using the software ART Optix Optiview (ART Inc., Montreal, QC, Canada). The software normalizes all images obtained in the same experimental run (i.e., paired animals, same injected solution) to the same fluorescent scale (expressed in arbitrary units). After the last scan, the mice were cardiac-punctured and then perfused transcardially with 50-mL cold saline with a peristaltic ISMATECH pump (IDEX Health \& Science GmbH. Germany) at $5 \mathrm{~mL} / \mathrm{min}$ for $10 \mathrm{~min}$ to wash out the remaining blood and circulating fluorescence. Brains were then extracted and scanned ex-vivo for fluorescence concentration

\section{Immunohistochemistry}

To demonstrate the presence of $A \beta$ peptides in the brain, the brains extracted at the end of the imaging protocol were frozen-sectioned at $10 \mu \mathrm{m}$ and immunostained with a mouse monoclonal anti-human $A \beta$ antibody $6 \mathrm{E} 10$ and a goat anti-mouse secondary antibody conjugated with Alexa 568 as described $[3,4,8]$. The sections were also counterstained with fluorescein-labeled lectin, Ulex europeaus agglutinin (UEA-I), as described [28] to visualize cerebral vessels. 


\section{Statistical analysis}

The fluorescent concentrations in mouse brains were compared by one-way ANOVA followed by NewmanKeuls post-hoc test.

\section{Results}

Is Cy5.5 a substrate for mdr-1 P-glycoprotein or ABCG2?

To enable prospective in vivo optical imaging of the distribution of peripherally-injected $A \beta$ peptides, the peptides were labeled with the near-infrared fluorescent dye Cy5.5. Since the principal aim of the present study was to monitor brain distribution of Cy5.5-labeled $A \beta$ peptide in mice lacking major $\mathrm{ABC}$ transporters, the fluorescent tracer itself should not be the substrate for these transporters. To compare the permeability of $\mathrm{BBB}$ for Cy5.5 in wild-type, $\mathrm{Abcb} 1^{-\mathrm{KO}}$ and $\mathrm{Abcg} 2^{-\mathrm{KO}}$ animals, equal amounts of Cy5.5 tracer were intravenously injected into two pairs of wild-type and knockout mice; concentration of Cy5.5 fluorescence in their heads was determined by prospective optical imaging between 2 and $8 \mathrm{~h}$ after injection. The plasma half-life of Cy5.5 is about $30 \mathrm{~min}$ and the majority of the dye is cleared from the body in 2 hours. Remaining fluorescence in the head ROI was close to background and was not different between wildtype and $\mathrm{Abcg} 2^{-\mathrm{KO}}$ (Figure 1) or $\mathrm{Abcb}^{-\mathrm{KO}}$ (not shown) animals. Data indicate that the BBB in both wt and ABCknockout animals is equally restrictive to Cy5.5, consistent with its molecular weight (1128.42D) and our previous observation that Cy5.5 can be detected in the brain only after the BBB breakdown $[24,25]$. Furthermore, since the deficiency in either mdr-1 P-glycoprotein (Abcb1) or Abcg2 has been shown not to affect BBB tight-junctions /passive permeability [29], the absence of brain accumulation of systemic Cy5.5 in these animals indicated that Cy5.5 is not a substrate for these transporters and can be used as fluorescent imaging tracer for $A \beta$ tracking after systemic injection.

\section{Stability of $A \beta-C y 5.5$ conjugates in serum}

The stability of A $\beta-C y 5.5$ conjugates in serum was evaluated ex vivo by exposing conjugates to the intact, non-inactivated FBS or PBS for up to $8 \mathrm{~h}$ at $37^{\circ} \mathrm{C}$. The dilutions $(1: 8 \mathrm{v} / \mathrm{v})$ of the $\mathrm{A} \beta-\mathrm{Cy} 5.5$ conjugates in FBS and PBS were adjusted to represent circulatory dilution after i.v. injection of $200 \mu \mathrm{L} A \beta-C y 5.5$ conjugates into adult mouse. Cy5.5-labeled $A \beta$ peptides resolved on a tricine-SDS-PAGE gel were imaged in eXplore Optix, showing the presence of Cy5.5-signal after the exposure to either FBS or PBS for up to $8 \mathrm{~h}$ (Figure 2A). Immunoblots of the same tricine-SDS-PAGE gels using 6E10 anti-A $\beta$ antibody (Figure 2B), showed single bands with similar mobility as unlabeled $A \beta$. Although the resolution of gels was not sufficient to resolve differences in MW (1-3 kD) between Cy5.5labeled and unlabeled $A \beta$, no appreciable reductions of intact $A \beta$ peptide bands were observed after incubation in either PBS or FBS, suggesting that A $\beta-C y 5.5$ conjugates were mostly intact in the serum ex vivo up to 8 hours.

\section{Brain accumulation of $A \beta_{1-40}$ and scrambled $A \beta_{40-1}$}

The biodistribution and systemic elimination (pharmacokinetics) of A $\beta-C y 5.5$ was evaluated by serial wholebody imaging after i.v. injection of labeled peptides into wild-type and transporter knockout animals. Our recent work demonstrated that the fluorescence residence time evaluated by whole-body imaging correlates closely with the circulation half-life of injected Cy5.5-labeled proteins [30]. The elimination kinetics of injected A $\beta-C y 5.5$ were similar in the wild-type and Abcg2-KO (Figure $3 \mathrm{~A}$ ) and $\mathrm{Abcb1}^{-\mathrm{KO}}$ (not shown), showing almost complete disappearance of fluorescence from the body between $2 \mathrm{~h}$ and $4 \mathrm{~h}$ after injection. The only discernible difference was the increased head fluorescence signal in transporter $\mathrm{KO}$ animals (Figure 3A).

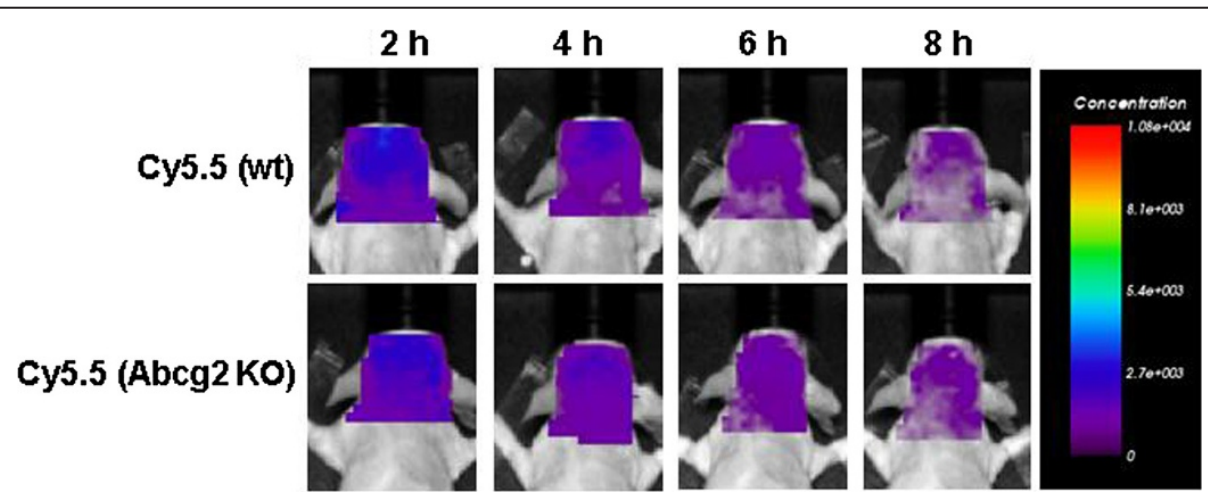

Figure 1 Serial images of the concentration of the near-infrared fluorescent tracer Cy5.5 in the head region (ROI) after intravenous injection in wild-type and Abcg2 ${ }^{-\mathrm{KO}}$ mice. Cy5.5 free dye ( $78 \mu \mathrm{g}$ in $200 \mu \mathrm{L}$ saline) was injected i.v. and mice were repeatedly imaged at 2, 4, 6 and $8 \mathrm{~h}$ using the explore Optix 670. The images shown were analyzed using ART Optix Optiview software and are representative of 4 animals per group. 


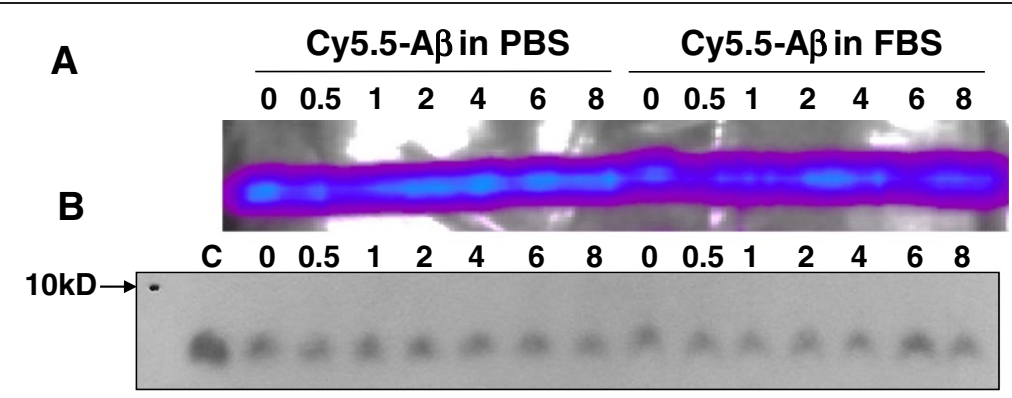

Figure 2 The stability of $C y 5.5$-labeled $A \beta_{1-40}$ peptide in serum ex vivo. Cy5.5-labeled $A \beta_{1-40}$ peptides were incubated in either phosphate buffered saline (PBS) or fetal bovine serum (FBS) at $37^{\circ} \mathrm{C}$ for indicated periods of time, resolved on a $16 \%$ Tricine-SDS-PAGE gel, imaged using eXplore Optix optical imager (A), and then blotted to PVDF membrane and probed with the anti-human A 3 antibody 6 E10 (B). The lane C contains $1 \mu \mathrm{g}$ unlabeled Aß peptide; all other lanes contain $\sim 1 \mu \mathrm{g}$ Cy5.5-labeled Aß peptides.
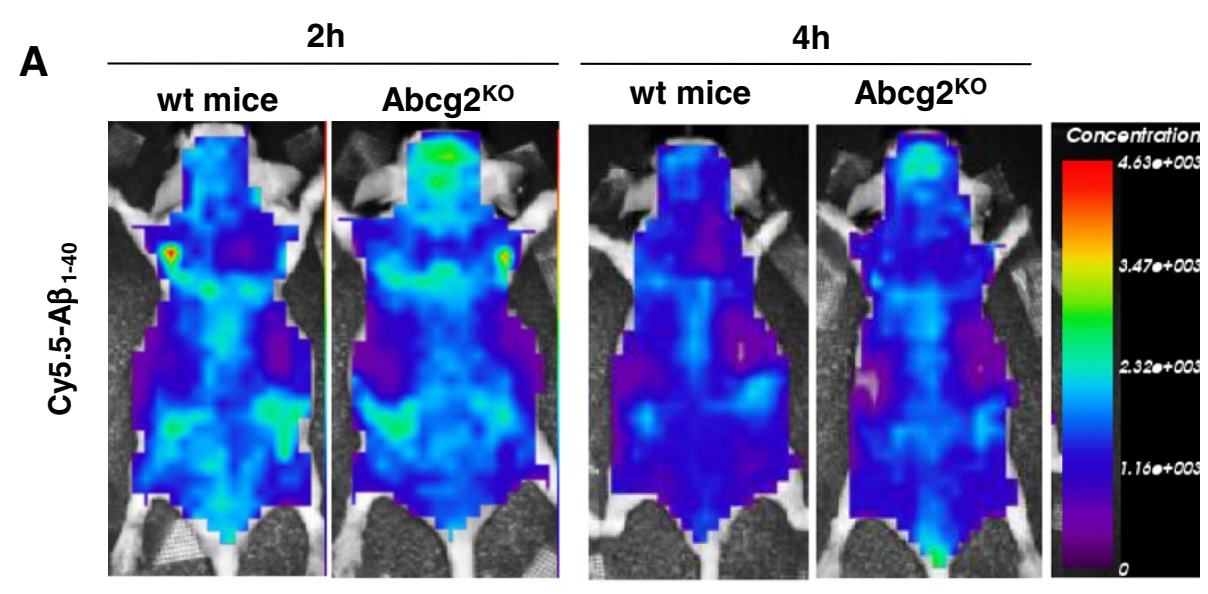

B

$2 \mathrm{~h}$

$4 \mathrm{~h}$
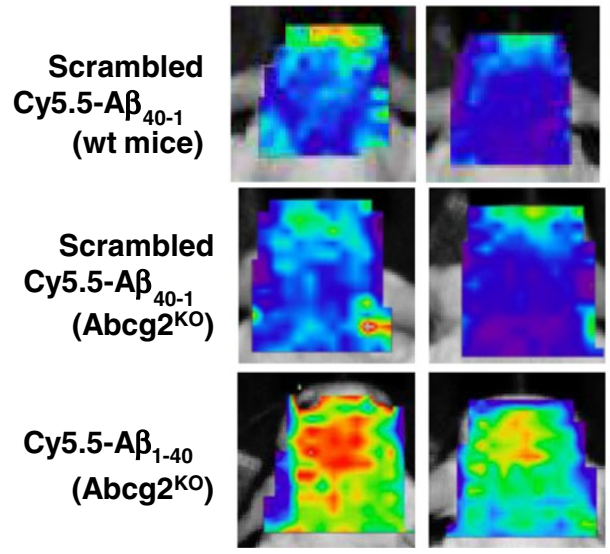

$6 \mathrm{~h}$

$8 \mathrm{~h}$

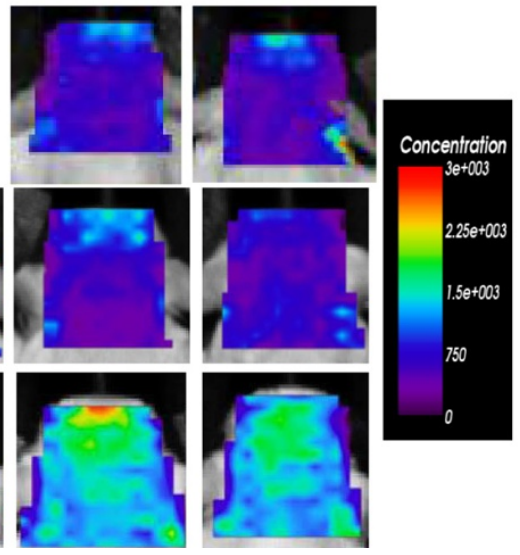

Figure 3 Serial concentration images of $A b c g 2^{-K O}$ and wild-type mice injected i.v. with either Cy5.5-labeled scrambled $A \beta_{40-1}$ or $A \beta_{1-40}$ peptides. The peptides (100 $\mathrm{\mu g}$ in $200 \mu \mathrm{L}$ volume) were injected i.v. and whole body and head ROls of animals were imaged at 2, 4, 6, and $8 \mathrm{~h}$ using the explore Optix 670. Panel A shows the whole body (dorsal) images of wild-type and Abcg $2^{-K O}$ mice 2 and $4 \mathrm{~h}$ after i.v. injection of Cy5.5- $A \beta_{1-40}$. Panel $\mathbf{B}$ shows head ROI fluorescence concentration images over time in wild-type mice injected with scrambled $A \beta_{40-1}$, and $A b c g 2^{-K O}$ mice injected with either Cy5.5-labeled scrambled $A \beta_{40-1}$ or with Cy5.5-labeled $A \beta_{1-40}$ peptide. The images shown were analyzed with ART Optix Optiview software and are representative of 4 animals per group. 
Another important control for this study was to determine whether the observed accumulation of Cy5.5-labeled $A \beta_{1-40}$ in the head region of $K O$ animals was $A \beta_{1-}$ 40. Therefore, Cy5.5-labeled scrambled $A \beta_{40-1}$ was used in comparative experiments. After systemic injections of the equimolar concentrations (and equal fluorescence intensity) of Cy5.5-labeled peptides, the imaged head concentrations of scrambled $A \beta_{40-1}$ were similar in wildtype and $\mathrm{Abcg} 2^{-\mathrm{KO}}$ (Figure $3 \mathrm{~B}$ ) or $\mathrm{Abcb} 1^{-\mathrm{KO}}$ mice (data not shown), while concentrations of $A \beta_{1-40}$ were consistently higher than those of scrambled $A \beta_{40-1}$ in $A b c g 2^{-\mathrm{KO}}$ mice (Figure $3 \mathrm{~B}$ ). These observations suggested that only $A \beta_{1-40}$, but not its scrambled version, is trafficked from the circulation into the brain, likely through binding to specific brain endothelial receptors/transporters.

Brain accumulation of blood-borne $A \beta_{1-40}$ peptides in Abcg2- or Abcb1- knockout animals

To evaluate whether there are differences in brain accumulation of blood-borne $A \beta_{1-40}$ between wild-type and
ABC-transporter-deficient animals, four pairs of adult wild-type and $A b c b 1^{-\mathrm{KO}}$ mice and five pairs of adult wild-type and $\mathrm{Abcg} 2^{-\mathrm{KO}}$ mice were intravenously injected via the tail vein with the same amount of Cy5.5labeled $A \beta_{1-40}$ peptides and imaged prospectively over $2-8 \mathrm{~h}$ period. At the end of the protocol, mice were perfused with 50-mL cold saline and their brains were also imaged ex vivo.

The circulation half-life of injected ${ }^{125} \mathrm{I}-\mathrm{A} \beta$ peptides is about 35-45 $\mathrm{min}[31,32]$. Therefore, the initial imaging time point of 2 hours (3-4 half-lives) was chosen to allow for a substantial clearance of the tracer from the circulation (also shown in Figure 3A). Therefore, fluorescence concentrations measured in the head ROI are assumed to represent mostly non-circulatory tracer, either bound/internalized into the brain vessels or transported into the brain parenchyma.

Comparisons of fluorescent concentrations in the head ROIs indicated that the fluorescence concentration of the tracer is statistically higher (133\%) in Abcg $2^{-\mathrm{KO}}$ mice

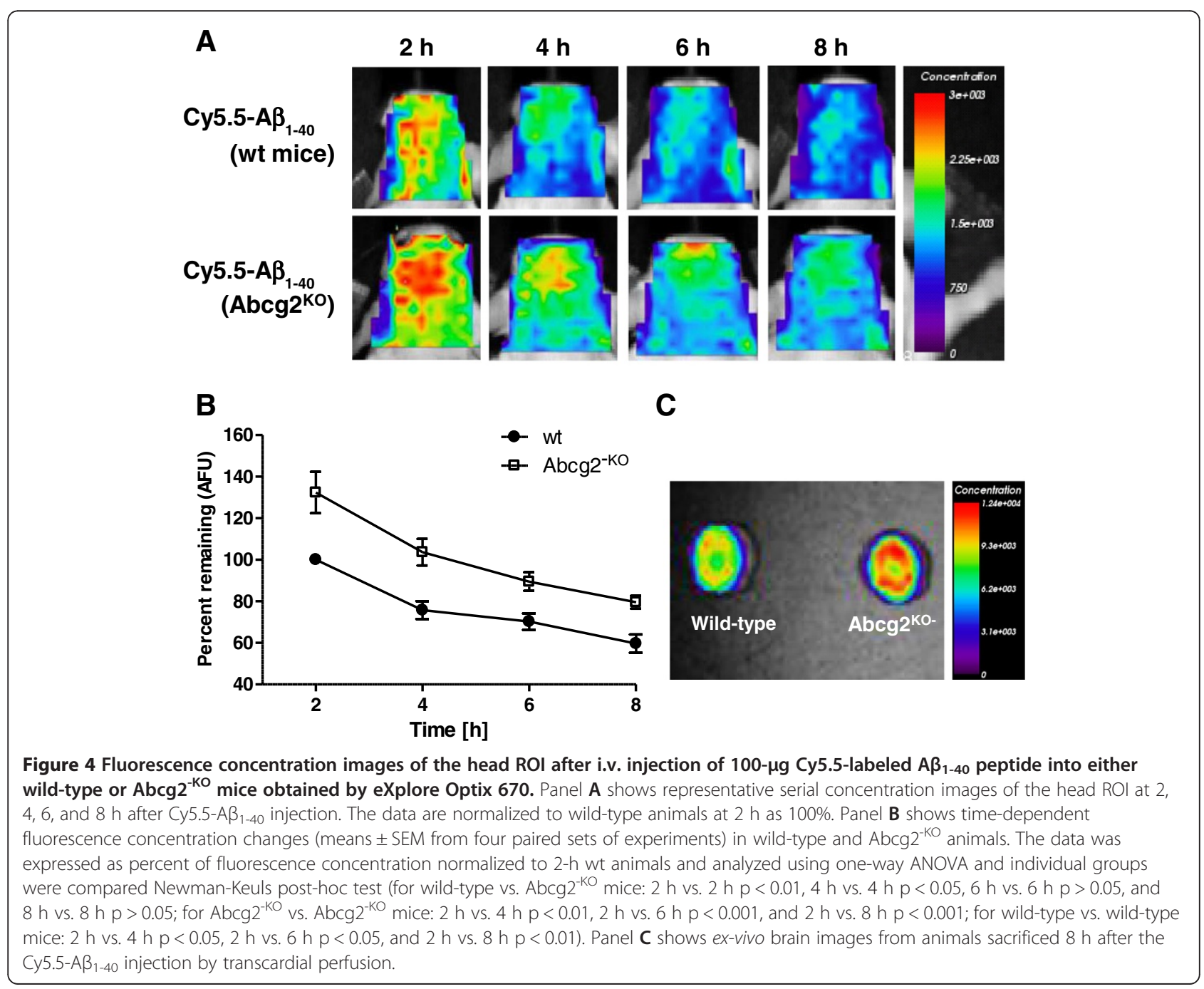


compared to wild-type mice at each time point assessed (Figure 4A, B). However, fluorescence decay curves over 2-8 h (analyzed using one-phase exponential decay) indicated similar decay dynamics in $\mathrm{Abcg} 2^{-\mathrm{KO}}$ mice $\left(\mathrm{t}_{1 / 2}=\right.$ $2.34 \mathrm{~h})$ compared to wild-type $\left(t_{1 / 2}=1.97 \mathrm{~h}\right)$. Imaging of perfused brains ex vivo (Figure $4 \mathrm{C}$ ), indicated that brain fluorescence levels remained elevated in $\mathrm{Abcg} 2^{-\mathrm{KO}}$ mice in comparison to wild-type animals $8 \mathrm{~h}$ after injection.

The head fluorescence concentrations in $A b c b 1^{-\mathrm{KO}}$ mice was also significantly higher than in wild-type mice at the outset of imaging measurements (2 hours) (124.2\% in $\mathrm{Abcb}^{-\mathrm{KO}}$ mice normalized to wild-type mice at $2 \mathrm{~h}$ as 100\%) (Figure 5A, B). The fluorescence concentration 'decay' over 2-8 h, showed slightly faster decay dynamics in $\mathrm{Abcb}^{-\mathrm{KO}}$ mice $\left(\mathrm{t}_{1 / 2}=1.38 \mathrm{~h}\right)$ compared to wt-type $\left(t_{1 / 2}=1.97 \mathrm{~h}\right)$ (Figure $5 \mathrm{~B}$ ). At the end of the imaging protocol perfused brains were imaged ex-vivo (Figure 5C), confirming that the fluorescence concentration differences observed in vivo were not due to circulating tracer.

\section{Immunohistochemistry detects $A \beta$ peptides in mouse brain}

To determine whether measured Cy5.5 fluorescence in imaging experiments originated from the intact $\mathrm{Cy} 5.5-\mathrm{A} \beta_{1-40}$ conjugates rather than from the proteolytically-degraded fragments or dye alone, $A \beta$ peptides were detected in the brain tissues of wild-type and $\mathrm{Abcg} 2^{-\mathrm{KO}}$ mice using an anti$A \beta$ antibody, 6E10. Brain sections probed with secondary antibody only (Figure 6A \& B) showed no detectable signal. The immunoreactive $A \beta$ (red) was detected in brain sections of both wild-type and $\mathrm{Abcg} 2^{-\mathrm{KO}}$ animals injected with Cy5.5-labeled $A \beta_{1-40}$ peptides (Figure $6 C \& D$ ). $A \beta$ was observed co-localizing with brain vessels as well as within brain parenchyma (Figure 6E \& F).

6 E10 antibody recognizes human, but not murine (endogenous) form of $A \beta$ peptides. In our previous study [33] investigating the expression of $A \beta_{1-40}$ and $A \beta_{1-42}$ in the brains of wild-type, $\mathrm{Abcg} 2^{-\mathrm{KO}}, \mathrm{Tg}-\mathrm{SwDI}$, and double transgenic Tg-SwDI/Abcg2-KO mice up to 15 months of age, murine forms of $\mathrm{A} \beta$ peptides were below detection
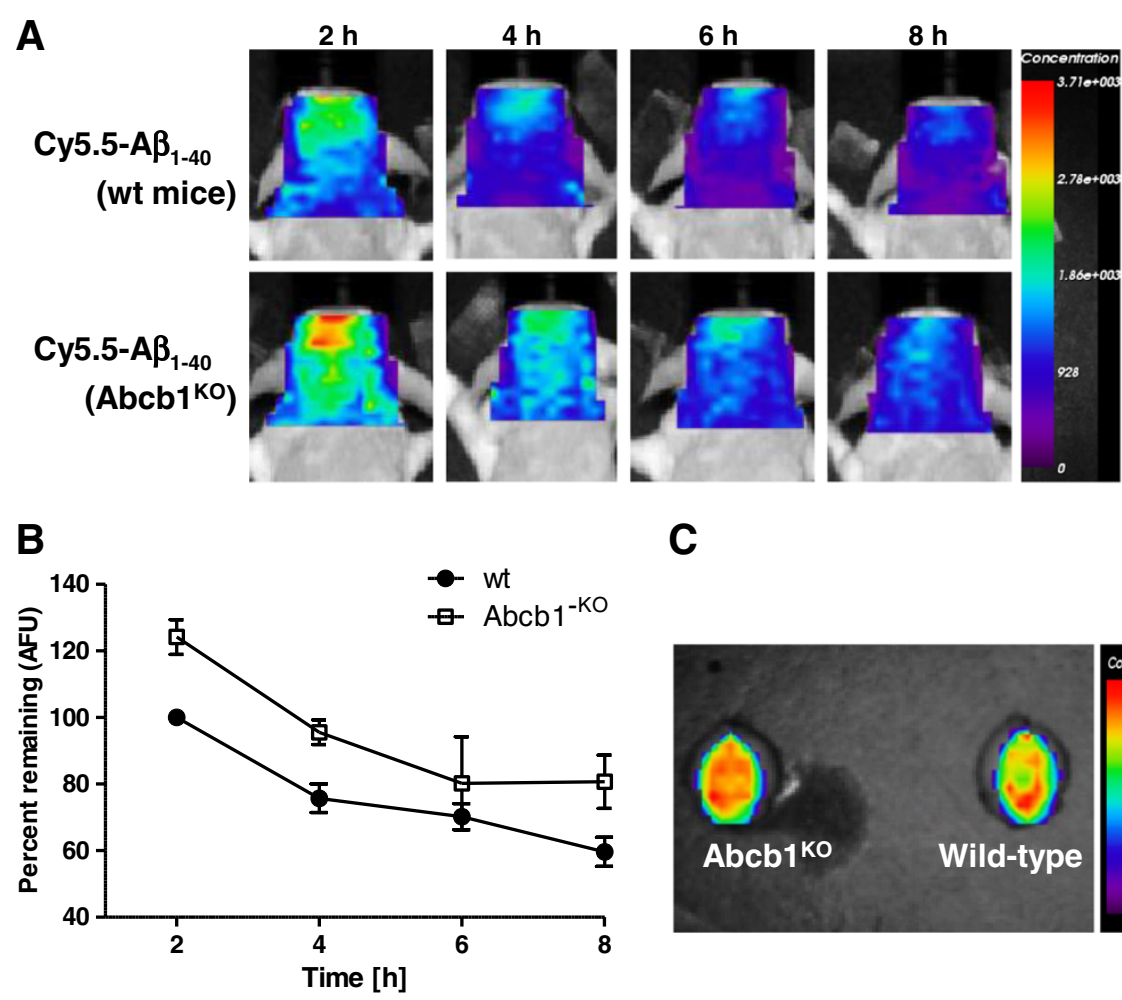

C

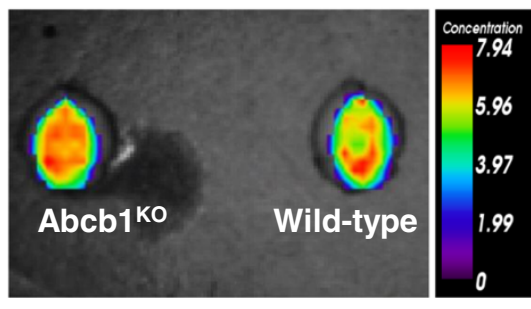

Figure 5 Fluorescence concentration images of the head ROI after i.v. injection of $100-\mu \mathrm{g} C y 5.5$-labeled $A \beta_{1-40}$ peptide into either wild-type or $\mathbf{A b c b} 1^{-\mathrm{KO}}$ mice obtained by eXplore Optix 670. Panel $\mathbf{A}$ shows representative serial concentration images of the head ROI at 2 , 4, 6, and $8 \mathrm{~h}$ after $C y 5.5-A \beta_{1-40}$ injection. The data are normalized to wild-type animals at $2 \mathrm{~h}$ as $100 \%$. Panel $\mathbf{B}$ shows time-dependent fluorescence concentration changes (means \pm SEM from four paired sets of experiments) in wild-type and Abcb $1^{-\mathrm{KO}}$ animals. The data was expressed as percent of fluorescence concentration normalized to $2-h$ wt animals and analyzed using one-way ANOVA and individual groups were compared Newman-Keuls post-hoc test (for wild-type vs. Abcb1-KO mice: $2 \mathrm{~h}$ vs. $2 \mathrm{~h} \mathrm{p}<0.05,4 \mathrm{~h}$ vs. $4 \mathrm{~h} \mathrm{p}>0.05,6 \mathrm{~h}$ vs. $6 \mathrm{~h} \mathrm{p}>0.05$, and $8 \mathrm{~h}$ vs. 8 h p $>0.05$; for Abcb1 ${ }^{-\mathrm{KO}}$ vs. Abcb1 ${ }^{-\mathrm{KO}}$ mice: 2 h vs. $4 \mathrm{~h} \mathrm{p}<0.05,2 \mathrm{~h}$ vs. $6 \mathrm{~h} \mathrm{p}<0.01$, and $2 \mathrm{~h}$ vs. $8 \mathrm{~h} \mathrm{p}<0.001$; for wild-type vs. wild-type mice: 2 h vs. 4 h p > 0.05, 2 h vs. 6 h $p<0.05$, and 2 h vs. 8 h $p<0.001)$. Panel $C$ shows ex-vivo brain images from animals sacrificed 8 h after the Cy5.5-A $\beta_{1-40}$ injection by transcardial perfusion. 

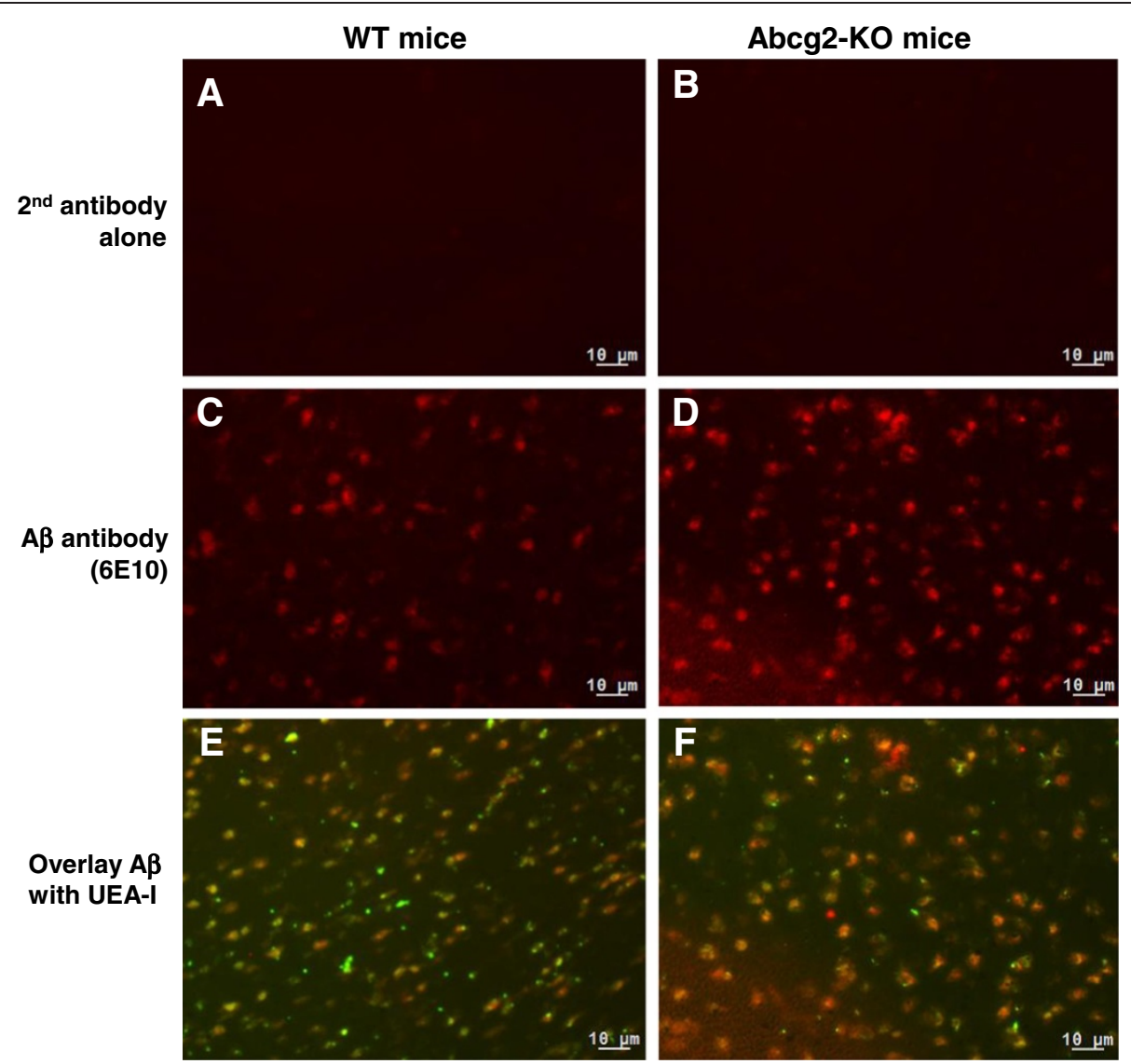

Figure $6 \mathrm{~A} \beta_{1-40}$ immunohistochemistry in brain sections using a mouse monoclonal anti-A $\boldsymbol{\beta}$ antibody $6 \mathrm{E} 10$. The wild-type and $\mathrm{Abcg} 2^{-\mathrm{KO}}$ mice were injected with $100 \mu \mathrm{g}$ Cy5.5-labeled human $A \beta_{1-40}$ peptides and brain tissues were collected $8 \mathrm{~h}$ post-injection. Brain sections were incubated with either the secondary antibody alone (panels A \& B) or 6 E10 followed with the Alexa 568 (red)-conjugated secondary antibody (panels $\mathbf{C} \& \mathbf{D}$ ) and were co-stained with UEA-I (green) to visualize cerebral vessels (panels $\mathbf{E} \& \mathbf{F}$ ). Images ( $20 \times$ magnifications) are representative of results obtained from 3 animals in each group.

limits (Mouse $A \beta$ ELISA kits, Invitrogen Inc), whereas human forms were detected in Tg-SwDI, and double transgenic Tg-SwDI/Abcg2 ${ }^{-\mathrm{KO}}$ mice. Therefore, the presence of immunoreactive $A \beta$ in the mouse brain after i.v. injection of Cy5.5-labeled human $A \beta$ peptides suggested that these peptides were blood-borne and confirmed that at least a portion of imaging signal originated from intact $\mathrm{A} \beta-\mathrm{Cy} 5.5$ conjugates.

\section{Discussion}

This study describes the application of prospective in vivo optical imaging protocols to study brain accumulation of systemically injected $A \beta$ peptides in wild-type and animals deficient in specific transporters previously implicated in $A \beta$ transport across the blood-brain barrier.

Radio-labeled $\left[{ }^{125} \mathrm{I}\right]$-or $\left[{ }^{3} \mathrm{H}\right]-\mathrm{A} \beta$ peptides have been used to study their BBB transport in animal models. The labelled peptides are either injected intravenously to analyze brain uptake or intra-cerebrally to investigate their clearance from the brain; animals are sacrificed at different time points and the radioactivity is determined in desired compartments. In vivo molecular imaging approaches that 'track' $A \beta$ peptides non-invasively are dynamic methods that can be used for assessing $A \beta$ levels in response to treatments. Notably, PET imaging with $\left[\mathrm{C}^{11}\right]$-PiB [ $N$-methyl-[11C]2-(4-methylaminophenyl)6-hydroxybenzothiazole] has been used for quantitative assessment of brain $\mathrm{A} \beta$ load in Alzheimer's patients [34] and in APP/PS1 mouse [22]. Apart from requiring 'onsite' radioisotope labeling and access to expensive PET equipment, this approach is not applicable for 'tracking' peripheral $\mathrm{A} \beta$ peptides. Optical molecular imaging/ tracking of $A \beta$ peptides functionalized with the nearinfrared imaging tracer is a viable alternative that can provide high sensitivity in experimental setting, although it does not have the quantification capabilities of PET. Among in vivo optical imaging systems, time-domain optical imaging has a clear advantage over Continuous Wavelength $(\mathrm{CW})$ systems in that its pulsed laser source 
can penetrate skull to excite the fluorescent tracer in deep tissues. In contrast to $\mathrm{CW}$ systems where emitted light is collected by a CCD camera that cannot resolve the depth of the signal, with time-resolved imaging platform each collected photon retains time-of-flight distribution (also called a Temporal Point Spread Function or TPSF) from which depth (optical tomography), fluorescence concentration and fluorescence lifetime can be extracted [24-27]. This and other studies $[35,36]$ have shown that this imaging method is a useful non-invasive approach to investigate $A \beta$ transport, distribution, and clearance from the brain that complements other imaging approaches.

The aberrant transport and clearance of $A \beta$ peptides across the $\mathrm{BBB}$, mediated by a spectrum of receptors and transporters including RAGE, LRP-1, and members of $\mathrm{ABC}$ family, contributes to $\mathrm{A} \beta$ accumulation in the brain and in the cerebral vasculature [7,37,38]. ABC family members MDR-1 P-glycoprotein/ABCB1 and ABCG2/BCRP are two major drug efflux transporters located at the luminal surface of the BBB $[39,40]$. In mice, mdr-1a (Abcb1a) is the primary drug efflux transporter expressed at the BBB; while mdr-1b (Abcb1b) is the main isoform detected in the brain parenchyma [41]. Murine mdr-1 P-glycoprotein is encoded by both $m d r$ $1 a(A b c b 1 a)$ and $m d r-1 b(A b c b 1 b)$, which share $90 \%$ sequence homology and have $80 \%$ homology to human MDR1 (ABCB1). The mdr-1a/b (Abcb1a/b) double knockout completely eliminates mdr-1-mediated transport activity at the BBB. Several published studies [8,15-20] presented the evidence that inhibition or deficiency of Abcg2 or mdr-1 P-glycoprotein increases $A \beta$ intake in cell models and reduces brain $A \beta$ clearance in animal models.

To further evaluate the roles of Abcb1 and Abcg2 in $\mathrm{A} \beta$ trafficking across the $\mathrm{BBB}$, we developed the noninvasive optical imaging method for 'tracking' systemically injected fluorescently-labeled $A \beta$ peptides in $A b c b 1^{-\mathrm{KO}}$ and $\mathrm{Abcg} 2^{-\mathrm{KO}}$ mice. For the purpose of in vivo tracking $\mathrm{A} \beta$ peptides were conjugated to the near-infrared optical fluorescence tracer Cy5.5. Since A $\beta$ degrading proteases including insulin degrading enzyme (IDE), angiotensin converting enzyme (ACE) and neprilysin $[42,43]$ are active in the blood and can contribute to $A \beta$ degradation, the stability of Cy5.5-A $\beta$ conjugates in serum over 8 hours was confirmed ex-vivo, proving that the optical signal in imaging experiments originated predominantly from intact Cy5.5-A $\beta$ conjugates. Imaging assessment of the whole-body biodistribution and elimination kinetics of Cy5.5-A $\beta$ peptides, demonstrated similar elimination kinetics in wild-type and $\mathrm{KO}$ animals; the majority of peripheral tracer was eliminated by $2-4 \mathrm{~h}$ after the injection. This is in agreement with previous studies that reported the circulation half-life of injected $\left[{ }^{125} \mathrm{I}\right]-\mathrm{A} \beta$ peptides of about 35-45 $\mathrm{min} ; \sim 81 \%$ of the injected $\mathrm{A} \beta$ was cleared from blood by $60 \mathrm{~min}$ after administration in adult monkey $[32,33,44]$.

Head ROI imaging protocols were initiated 2 hours after tracer injection, allowing 3-4 circulation half-lives; therefore, measured head fluorescence concentration was primarily indicative of the brain-accumulated/ retained tracer, with small contribution of circulating tracer. In both $\mathrm{Abcb} 1^{-\mathrm{KO}}$ and $\mathrm{Abcg} 2^{-\mathrm{KO}}$ animals, brain tracer concentration was higher than in the wild-type animals at 2 hours, suggesting that any of the following processes or their combination might have been altered in knockout animals: a) the rate of $\mathrm{A} \beta$ brain influx was increased; b) the rate of $\mathrm{A} \beta$ brain elimination was slower; and c) A $\beta$ binding/uptake into brain vessels was increased. Based on the current data, we cannot exclude any of these processes being responsible for the observed tracer concentration differences at 2 hours after injection. However, given the relatively short circulation half-life of $A \beta$, we can assume that imaging measurements between 2 and 8 hours after injection reflect predominantly brain elimination kinetics of $A \beta$. Brain-injected $\left[{ }^{125} \mathrm{I}\right]-\mathrm{A} \beta_{1-40}$ peptide has been shown to clear rapidly via receptor-mediated transport with $t_{1 / 2}$ of 25 minutes [45]. A single photon emission computed tomography (SPECT) study in squirrel monkeys [46], demonstrated a bi-phasic brain clearance of intracerebrally microinfused $\left[{ }^{123} \mathrm{I}\right]-\mathrm{A} \beta_{1-40}$, with short $\mathrm{t}_{1 / 2}$ ranging from $1.1 \sim 2.7$ hours and accompanying plasma appearance of $\left[{ }^{123} \mathrm{I}\right]-\mathrm{A} \beta_{1-40}$, suggesting active brain-to-blood transport. Comparisons of $A \beta$ fluorescence decay curves between 2 and $8 \mathrm{~h}$ in wild-type and $\mathrm{ABC}$-transporter knock-out animals indicated similar fluorescence decay (elimination) kinetics within the range of clearance rates described by Bading et al [46]. Due to limited number of imaging time-points and the study design, it was not possible to discern whether the observed elimination kinetics of $A \beta$ are due to active reverse transport across the $\mathrm{BBB}$ or to the interstitial fluid bulk-flow clearance.

Whereas lack of Abcg2 in this study did not appear to affect the rate of $A \beta$ elimination from the brain, it resulted in higher initial accumulation of injected $A \beta$, suggesting that it has a role in either limiting brain access of circulating $A \beta$ or mediating fast brain elimination phase of $A \beta$, or both. In agreement with our observations, a recent study [15] using the in situ brain perfusion technique showed that GF120918, a dual inhibitor of Abcb1 and Abcg2, strongly enhanced the uptake of $\left[{ }^{3} \mathrm{H}\right]-\mathrm{A} \beta_{1-40}$ in the brains of Abcb1-deficient mice, but not in the brains of Abcb1/Abcg2-deficient mice. ABCG2 is up-regulated in human $\mathrm{AD}$ brain with cerebral amyloid angiopathy (CAA) [8] where it modulates $A \beta$-induced vascular oxidative stress $[33,47]$.

Similarly, the deficiency of mdr-1/P-glcoprotein significantly increased brain accumulation of systemically injected $\mathrm{A} \beta$ but also slightly accelerated its elimination 
from the brain. This observation is consistent with some previously reported studies. Deposition of $A \beta$ peptides has been found to inversely correlate with MDR-1 Pglycoprotein/ABCB1 expression in the brains of elderly non-demented humans as well as in the brains of Alzheimer's patients $[37,48,49]$. In addition, $A \beta$ was found to down-regulate BBB mdr-1 P-glycoprotein (Abcb1) expression in mice [50]. Cirrito and colleagues [17] demonstrated that $A \beta$ removal from the brain was partially mdr-1-dependent in mdr-1a/b KO mice. Furthermore, restoration of mdr-1 P-glycoprotein/Abcb1 at the BBB by PXR (Pregnane X Receptor) agonist reduced brain $A \beta$ load in a mouse model of Alzheimer's disease [18].

The definitive interpretation of data provided in this study is confounded by possible activation of compensatory mechanisms in knock-out animals. For example, the Abcb1/P-glycoprotein-null mice were found to have lower brain expression of LRP-1 compared to wild-type mice [17]. We found no compensatory changes in Abcb1a/mdr-1a and Abcb1b/mdr-1b expression in the brains of $\mathrm{Abcg} 2^{-\mathrm{KO}}$ mice (data not shown); however, we cannot ascertain whether other $A \beta$ transporters (i.e., RAGE, LRPs) were specifically affected in brain endothelial cells in Abcb1- or Abcg2 $2^{-\mathrm{KO}}$ animals.

Pharmacological studies using selective inhibitors of BBB transporters in cell systems [15,20] provided strong evidence that both ABCB1/MDR-1 P-glycoprotein and ABCG2 have the capacity to interact with and shuttle $A \beta$ across cellular membranes. In vivo imaging studies, including ours presented here, support this notion and provide means for dynamic analyses of integrative influences of $\mathrm{BBB}$ transporters on $\mathrm{A} \beta$ trafficking in and out of the brain.

In summary, this study protocol describes potential application of time-domain prospective in vivo imaging in assessing $\mathrm{BBB}$ trafficking of systemically injected compounds, including $A \beta$ peptides, labeled with nearinfrared fluorescent imaging tracers. The protocol is particularly useful in assessing BBB trafficking of such compounds in animals exhibiting modifications of various BBB transporters, such as for example gene knockout or over-expression of ABC-family of efflux pumps. Similarly, this imaging method can be used to evaluate kinetics of brain elimination of intra-cerebrally-injected compounds as recently described in our study on FcRnmediated brain elimination of fluorescently-labeled macromolecules [51].

\footnotetext{
Abbreviations

AD: Alzheimer's disease; BBB: Blood-brain barrier; BCRP: Breast Cancer Resistant Protein; CW: Continuous Wavelength; FBS: Fetal bovine serum; HEPES: 4-(2-hydroxyethyl)-1-piperazineethanesulfonic acid; KO: Knockout; LRP-1: Low-density lipoprotein receptor-related protein-1; MDR: Multi-drug resistance; PiB: Pittsburgh compound B; PET: Positron-emission tomography; RAGE: Receptor for Advanced Glycation Endproducts; ROI: Region of interest; TPSF: Temporal Point Spread Function; wt: Wild-type; UEA-I: Ulex Europeaus Agglutinin-l.
}

\section{Competing interests}

The authors declare that they have no competing interests.

\section{Authors' contributions}

WZ conceived and designed the experiments, performed data analyses and prepared the figures, wrote and revised the manuscript. HX carried out most of the experiments and analyzed the data. AJ and KP assisted HX in performing the experiments. DC conducted brain tissue sections and $\mathrm{IHC}$. $\mathrm{HL}$ and EB conducted in vitro A $\beta$ stability assay. DF prepared and analyzed some of optical images. DS conceived the project and contributed to data analyses, figure preparation, writing and revising the manuscript. All authors have read and approved the final version of the manuscript.

\section{Acknowledgement}

This work was supported by funding from a Canadian Research Program "Vascular Health \& Dementia" sponsored by the Heart \& Stroke Foundation of Canada, Canadian Institute of Health Research (CIHR), Alzheimer Society of Canada and Pfizer, from CIHR (\#106886 and \#109606 to W. Z), and from the National Research Council of Canada. The authors thank Dr. A. Abulrob, Dr. Umar lqbal and Ms. Ewa Baumann for their help and advice.

\section{Author details}

${ }^{1}$ Human Health \& Therapeutics Portfolio, National Research Council of Canada, Ottawa, Canada. 'Faculty of Medicine, University of Ottawa, Ottawa, Canada. ${ }^{3}$ Current address: ApoPharma Inc., 100 Sussex Drive, Ottawa, Ontario K1A 0R6, Canada. ${ }^{4}$ Current address: The Hospital affiliated with the Shandong University of Traditional Chinese Medicine, Jinan, Shandong Province, China.

Received: 28 November 2012 Accepted: 22 February 2013 Published: 25 February 2013

\section{References}

1. Selkoe DJ, Schenk D: Alzheimer's disease: Molecular understanding predicts amyloid-based therapeutics. Annu Rev Pharmacol Toxicol 2002, 43:545-584.

2. Taylor JP, Hardy J, Fischbeck KH: Toxic proteins in neurodegenerative disease. Science 2002, 296:1991-1995.

3. Xiong $H$, Callaghan $D$, Jones A, Walker D, Lue L-H, Woulfe J, Beach TG, Sue $\mathrm{L}, \mathrm{Xu} \mathrm{H}$, Stanimirovic D, Zhang W: Cholesterol retention in Alzheimer's brain is responsible for high $\beta$-and $\gamma$-secretase activities and $A \beta$ production. Neurobiol Dis 2008, 29:422-437.

4. Vukic V, Callaghan D, Walker D, Lue L-H, Liu Q-Y, Couraud P-O, Romero IA, Weksler B, Stanimirovic DB, Zhang W: Expression of inflammatory genes induced by beta-amyloid peptides in human brain endothelial cells and in Alzheimer's brain is mediated by the JNK-AP1 signaling pathway. Neurobiol Dis 2009, 34:95-106.

5. Zlokovic BV: Neurodegeneration and the neurovascular unit. Nat Med 2010, 16:1370-1371.

6. Deane R, Bell RD, Sagare A, Zlokovic BV: Clearance of amyloid- $\beta$ peptide across the blood-brain barrier: Implication for therapies in Alzheimer's disease: Implication for therapies in Alzheimer's disease. CNS Neurol Disord Drug Targets 2009, 8:16-30.

7. Zlokovic BV: Neurovascular mechanisms of Alzheimer's neurodegeneration. Trends Neurosci 2005, 28:202-208.

8. Xiong H, Callaghan D, Jones A, Bai J-Y, Rasquinha I, Smith C, Walker D, Lue $\mathrm{L}-\mathrm{H}$, Pei K, Stanimirovic DB, Zhang W: ABCG2 is up-regulated in Alzheimer's brain with cerebral amyloid angiopathy and may act as a gatekeeper at the blood-brain barrier for A $\beta 1-40$ peptides. J Neurosci 2009, 29:5463-5475.

9. Zlokovic BV, Begley DJ, Chain-Eliash DG: Blood-brain barrier permeability to leucine-enkephalin, D-Alanine ${ }^{2}$-D-leucine ${ }^{5}$-enkephalin and their $\mathrm{N}$ terminal amino acid (tyrosine). Brain Res 1985, 336:125-132.

10. Zloković BV, Lipovac MN, Begley DJ, Davson H, Rakić L: Transport of leucine-enkephalin across the blood-brain barrier in the perfused guinea pig brain. J Neurochem 1987, 49:310-315.

11. Deane R, Du Yan S, Submamaryan RK, LaRue B, Jovanovic S, Hogg E, Welch D, Manness L, Lin C, Yu J, Zhu H, Ghiso J, Frangione B, Stern A, Schmidt AM, Armstrong DL, Arnold B, Liliensiek B, Nawroth P, Hofman F, Kindy M, Stern $D$, Zlokovic B: RAGE mediates amyloid-beta peptide transport across the blood-brain barrier and accumulation in brain. Nat Med 2003, 9:907-913. 
12. Deane $R$, Singh I, Sagare AP, Bell RD, Ross NT, LaRue B, Love R, Perry $S$, Paquette N, Deane RJ, Thiyagarajan M, Zarcone T, Fritz G, Friedman AE, Miller BL, Zlokovic BV: A multimodal RAGE-specific inhibitor reduces amyloid $\beta$-mediated brain disorder in a mouse model of Alzheimer disease. J Clin Invest 2012, 122:1377-1392.

13. Jaeger LB, Dohgu S, Hwang MC, Farr SA, Murphy MP, Fleegal-DeMotta MA, Lynch JL, Robinson SM, Niehoff ML, Johnson SN, Kumar VB, Banks WA: Testing the neurovascular hypothesis of Alzheimer's disease: LRP-1 antisense reduces blood-brain barrier clearance, increases brain levels of amyloid-beta protein, and impairs cognition. J Alzheimers Dis 2009, 17:553-570.

14. Zlokovic BV, Deane R, Sagare AP, Bell RD, Winkler EA: Low-density lipoprotein receptor-related protein-1: a serial clearance homeostatic mechanism controlling Alzheimer's amyloid $\beta$-peptide elimination from the brain. J Neurochem 2010, 115:1077-1189.

15. Do TM, Noel-Hudson MS, Ribes S, Besengez C, Smirnova M, Cisternino S, Buyse $M$, Calon F, Chimini G, Chacun H, Scherrmann JM, Farinotti R, Bourasset F: ABCG2- and ABCG4-mediated efflux of amyloid- $\beta$ peptide 1-40 at the mouse blood-brain barrier. J Alzheimers Dis 2012, 30:155-166.

16. Tai LM, Loughlin AJ, Male DK, Romero IA: P-glycoprotein and breast cancer resistance protein restrict apical-to-basolateral permeability of human brain endothelium to amyloid-beta. J Cereb Blood Flow Metab 2009, 29:1079-1083.

17. Cirrito JR, Deane R, Fagan AM, Spinner ML, Parsadanian M, Finn MB, Jiang $H$, Prior JL, Sagare A, Bales KR, Paul SM, Zlokovic BV, Piwnica-Worms D, Holtzman DM: P-glycoprotein deficiency at the blood-brain barrier increases amyloid-beta deposition in an Alzheimer disease mouse model. J Clin Invest 2005, 115:3285-3290.

18. Hartz AM, Miller DS, Bauer B: Restoring blood-brain barrier P-glycoprotein reduces brain amyloid-beta in a mouse model of Alzheimer's disease. Mol Pharmacol 2010, 77:715-723.

19. Lam FC, Liu R, Lu P, Shapiro AB, Renoir JM, Sharom FJ, Reiner PB: beta-Amyloid efflux mediated by p-glycoprotein. J Neurochem 2001, 76:1121-1128.

20. Kuhnke D, Jedlitschky G, Grube M, Krohn M, Jucker M, Mosyagin I, Cascorbi I, Walker LC, Kroemer HK, Warzok RW, Vogelgesang S: MDR1-PGlycoprotein (ABCB1) Mediates Transport of Alzheimer's amyloid-beta peptides-implications for the mechanisms of Abeta clearance at the blood-brain barrier. Brain Pathol 2007, 17:347-353.

21. Ghersi-Egea JF, Gorevic PD, Ghiso J, Frangione B, Patlak CS, Fenstermacher JD: Fate of cerebrospinal fluid-borne amyloid beta-peptide: rapid clearance into blood and appreciable accumulation by cerebral arteries. J Neurochem 1996, 67:880-883.

22. Manook A, Yousefi BH, Willuweit A, Platzer S, Reder S, Voss A, Huisman M, Settles M, Neff F, Velden J, Schoor M, von der Kammer H, Wester HJ, Schwaiger M, Henriksen G, Drzezga A: Small-animal PET imaging of amyloid-beta plaques with [11C]PiB and its multi-modal validation in an APP/PS1 mouse model of Alzheimer's disease. PLOS One 2012, 7:e31310.

23. Abulrob A, Brunette E, Slinn J, Baumann E, Stanimirovic D: Dynamic analysis of the blood-brain barrier disruption in experimental stroke using time domain in vivo fluorescence imaging. Mol Imaging 2008, 7:248-262.

24. Schägger H: Tricine-SDS-PAGE. Nature Protocol 2006, 16:16-22.

25. Abulrob A, Brunette E, Slinn J, Baumann E, Stanimirovic D: In vivo optical imaging of ischemic blood-brain barrier disruption. Methods $\mathrm{Mol}$ Biol 2011, 763:423-439.

26. labal U, Albaghdadi H, Luo Y, Arbabi M, Desvaux C, Veres T, Stanimirovic D, Abulrob A: Molecular imaging of glioblastoma multiforme using antiinsulin-like growth factor binding protein-7 single domain antibodies. $\mathrm{Br}$ J Cancer 2010, 103:1606-1616.

27. Iqbal U, Abulrob A, Stanimirovic DB: Integrated platform for brain imaging and drug delivery across the blood-brain barrier. Methods Mol Biol 2011, 686:465-481.

28. Zhang W, Mojsilovic-Petrovic J, Andrade M, Zhang H, Ball M, Stanimirovic D: Expression and Functional Characterization of ABCG2 in Brain Endothelial Cells and Vessels. FASEB J 2003, 17:2085-2087.

29. Agarwal S, Sane R, Gallardo JL, Ohlfest JR, Elmquist WF: Distribution of gefitinib to the brain is limited by P-glycoprotein (ABCB1) and breast cancer resistance protein (ABCG2)-mediated active efflux. J Pharmacol Exp Ther 2010, 334:147-155.

30. Lindhout T, Iqbal U, Willis LM, Reid AN, Li J, Liu X, Moreno M, Wakarchuk WW: Site-specific enzymatic polysialylation of therapeutic proteins using bacterial enzymes. Proc Natl Acad Sci USA 2011, 108:7397-7402.
31. Martel CL, Mackic JB, McComb JG, Ghiso J, Zlokovic BV: Blood-brain barrier uptake of the 40 and 42 amino acid sequences of circulating Alzheimer's amyloid beta in guinea pigs. Neurosci Lett 1996, 206(2-3):157-160

32. Mackic JB, Weiss MH, Miao W, Kirkman E, Ghiso J, Calero M, Bading J, Frangione B, Ziokovic BV: Cerebrovascular Accumulation and Increased Blood-Brain Barrier Permeability to Circulating Alzheimer's Amyloid $\beta$ Peptide in Aged Squirrel Monkey with Cerebral Amyloid Angiopathy. J Neurochem 1998, 70:210-215.

33. Zeng Y, Callaghan D, Xiong H, Yang Z, Huang P, Zhang W: Abcg2 deficiency augments oxidative stress and cognitive deficits in Tg-SwDI transgenic mice. J Neurochem 2012, 122:456-469.

34. Greenberg SM, Grabowski T, Gurol ME, Skehan ME, Nandigam RN, Becker JA, Garcia-Alloza M, Prada C, Frosch MP, Rosand J, Viswanathan A, Smith EE, Johnson KA: Detection of Isolated Cerebrovascular $\beta$-Amyloid with Pittsburgh Compound B. Ann Neurol 2008, 64:587-591.

35. Hillman EM: Optical brain imaging in vivo: techniques and applications from animal to man. J Biomed Opt 2007, 12:051402.

36. Evanko E: Optical imaging of the native brain. Nat Methods 2010, 7:34.

37. Jedlitschky G, Vogelgesang S, Kroemer HK: MDR1-P-glycoprotein (ABCB1)mediated disposition of amyloid- $\beta$ peptides: implications for the pathogenesis and therapy of Alzheimer's disease. Clin Pharmacol Ther 2010, 88:441-443.

38. Vogelgesang S, Jedlitschky G, Brenn A, Walker LC: The role of the ATP-binding cassette transporter P-glycoprotein in the transport of $\beta$-amyloid across the blood-brain barrier. Curr Pharm Des 2011, 17:2778-2786.

39. Zhang W, Stanimirovic DB: The transport systems of the blood-brain barrier. In The Blood-Brain Barrier and its Microenvironment: Basic Physiology to Neurological Disease. Edited by De Vries E, Prat A. New York: Taylor \& Francis Group; 2005:103-142.

40. Shen S, Zhang W: $A B C$ transporters and drug efflux at the blood-brain barrier. Re. Neuroscience 2010, 21:29-53.

41. Leslie EM, Deeley RG, Cole SPC: Multidrug resistance proteins: role of Pglycoprotein, MRP1, MRP2, and BCRP (ABCG2) in tissue defense. Toxicol Appl Pharmac 2005, 204:216-237.

42. Liu Z, Zhu H, Fang GG, Walsh K, Mwamburi M, Wolozin B, Abdul-Hay SO, Ikezu T, Leissring MA, Qiu WQ: Characterization of insulin degrading enzyme and other amyloid- $\beta$ degrading proteases in human serum: a role in Alzheimer's disease? J Alzheimers Dis 2012, 29:329-340.

43. Maetzler W, Stoycheva V, Schmid B, Schulte C, Hauser AK, Brockmann K, Melms A, Gasser T, Berg D: Neprilysin activity in cerebrospinal fluid is associated with dementia and amyloid- $\beta 42$ levels in Lewy body disease. J Alzheimers Dis 2010, 22:933-938.

44. Mackic JB, Bading J, Ghiso J, Walker L, Wisniewski T, Frangione B, Zlokovic BV: Circulating amyloid-beta peptide crosses the blood-brain barrier in aged monkeys and contributes to Alzheimer's disease lesions. Vascul Pharmacol 2002, 38:303-313.

45. Shibata M, Yamada S, Kumar SR, Calero M, Bading J, Frangione B, Holtzman DM, Miller CA, Strickland DK, Ghiso J, Zlokovic1 BV: Clearance of Alzheimer's amyloid-b1-40 peptide from brain by LDL receptorrelated protein-1 at the blood-brain barrier. J Clin Invest 2000, 106:1489-1499.

46. Bading JR, Yamada S, Mackic JB, Kirkman L, Miller C, Calero M, Ghiso J, Frangione B, Zlokovic BV: Brain clearance of Alzheimer's amyloid-beta40 in the squirrel monkey: a SPECT study in a primate model of cerebral amyloid angiopathy. J Drug Target 2002, 10:359-368.

47. Vogelgesang S, Cascorbi I, Schroeder E, Pahnke J, Kroemer HK, Siegmund W, Kunert-Keil C, Walker LC, Warzok RW: Deposition of Alzheimer's beta-amyloid is inversely correlated with P-glycoprotein expression in the brains of elderly non-demented humans. Pharmacogenetics 2002, 12:535-541.

48. Vogelgesang S, Warzok RW, Cascorbi I, Kunert-Keil C, Schroeder E, Kroemer HK, Siegmund W, Walker LC, Pahnke J: The role of Pglycoprotein in cerebral amyloid angiopathy; implications for the early pathogenesis of Alzheimer's disease. Curr Alzheimer Res 2004, 1:121-125.

49. Brenn A, Grube M, Peters M, Fischer A, Jedlitschky G, Kroemer HK, Warzok RW, Vogelgesang S: Beta-Amyloid Downregulates MDR1-P-Glycoprotein (Abcb1) Expression at the Blood-Brain Barrier in Mice. Int J Alzheimers Dis 2011, 2011:690121. 
50. Shen $\mathrm{S}$, Callaghan $\mathrm{D}$, Juzwik $C$, Xiong $H$, Huang $P$, Zhang W: ABCG2 reduces ROS-mediated toxicity and inflammation: A potential role in Alzheimer's disease. J Neurochem 2010, 114:1590-1604.

51. Caram-Salas N, Boileau E, Farrington GK, Garber E, Brunette E, Abulrob A Stanimirovic D: In vitro and in vivo methods for assessing FcRn-mediated reverse transcytosis across the blood-brain barrier. Methods Mol Biol 2011, 763:383-401.

doi:10.1186/2045-8118-10-13

Cite this article as: Zhang et al.: Blood-brain barrier transport of amyloid

beta peptides in efflux pump knock-out animals evaluated by in vivo optical imaging. Fluids and Barriers of the CNS 2013 10:13.

\section{Submit your next manuscript to BioMed Central and take full advantage of:}

- Convenient online submission

- Thorough peer review

- No space constraints or color figure charges

- Immediate publication on acceptance

- Inclusion in PubMed, CAS, Scopus and Google Scholar

- Research which is freely available for redistribution 